\title{
An evaluation of the effect of ertapenem in rats with sepsis created by cecal ligation and puncture
}

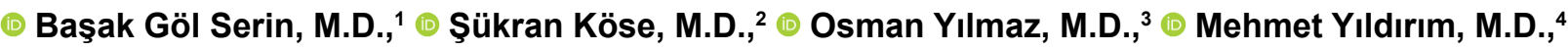

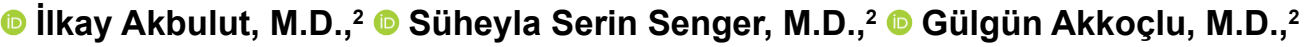 \\ (1) Gülden Diniz, M.D., ${ }^{5}$ ๑ Süha Serin, M.D. ${ }^{6}$
}

\begin{abstract}
${ }^{1}$ Department of Infectious Diseases and Clinical Microbiology, Hopa State Hospital, Artvin-Turkey
${ }^{2}$ Department of Infectious Diseases and Clinical Microbiology, University of Health Sciences Tepecik Training and Research Hospital, Izmir-Turkey ${ }^{3}$ Department of Laboratory Animal Science, Dokuz Eylül University Faculty of Medicine, İmir-Turkey

${ }^{4}$ Department of General Surgery, University of Health Sciences Bozyaka Training and Research Hospital, Izmir-Turkey

${ }^{5}$ Department of Pathology, University of Health Sciences Tepecik Training and Research Hospital, Izmir-Turkey

${ }^{6}$ Department of Emergency Medicine, Urla State Hospital, İzmir-Turkey
\end{abstract}

\begin{abstract}
BACKGROUND: Intra-abdominal adhesions are still a major problem which is expected to be reduced by the provision of bacterial decontamination. Various antibiotics have been used to prevent the formation of adhesion in the septic abdomen. This study aims to investigate the efficacy of ertapenem in sepsis of rats induced by cecal ligation and puncture.
\end{abstract}

METHODS: Twenty-eight Wistar rats were divided into four groups randomly. In all groups, bacterial peritonitis was created by cecal ligation and puncture method. Group I was considered as sham group. Groups 2, 3 and 4 were given, respectively, saline, a single dose of ertapenem and a dose of ertapenem intraperitoneally every day. Intra-abdominal adhesions were assessed seven days after surgery by histopathological examination. Microbiological examination was performed through the ascites obtained. TNF- $\alpha$ was measured from blood taken from rats.

RESULTS: Adhesion score decreased significantly by the application of ertapenem $(p<0.00 \mathrm{I})$ and fibrosis scores were found to be significantly lower $(p=0.005)$. Among all groups, the relationship between the decrease in the number of colonies and antibiotics application was not statistically significant $(p=0.109)$. No statistically significant difference was found between the group given a single dose of ertapenem and the group given multiple ertapenem $(p=I)$.

CONCLUSION: Peritoneal lavage with ertapenem appears to be effective in preventing the adhesion in the septic abdomen. As no difference was detected at the end of a single dose and multiple-dose administration of antibiotics in the adhesion scores, a single dose after surgery seems to be enough. The findings suggest that the results should be evaluated in a clinical trial.

Keywords: Ertapenem; rat; sepsis.

\section{INTRODUCTION}

Sepsis is an important cause of mortality and morbidity. Studies have shown that inflammatory mediators and cytokines are released during sepsis. ${ }^{[1]}$ Increased cytokine levels have been shown to correlate with the severity and mortality of the sepsis. ${ }^{[2]}$
Intra-abdominal sepsis and peritoneal adhesions occur as a part of the anatomical and functional regeneration process after the damage created by micro-organisms and toxins. These adhesions are made up of fibrin deposits and occur during the initial stage of inflammation. Cytokines also play a role in the formation of these adhesions. Fibrin deposits and intraabdominal adhesions are thought to be less common with

Cite this article as: Göl Serin B, Köse Ş, Yılmaz O, Yıldırım M, Akbulut İ, Serin Senger S, et al. An evaluation of the effect of ertapenem in rats with sepsis created by cecal ligation and puncture. Ulus Travma Acil Cerrahi Derg 2019;25:427-432.

Address for correspondence: Başak Göl Serin, M.D.

Hopa Devlet Hastanesi, Enfeksiyon Hastalıkları ve Klinik Mikrobiyoloji Bölümü, Artvin, Turkey

Tel: +90 466 - 35I 4017 / 2328 E-mail: bskgl87@hotmail.com

Ulus Travma Acil Cerrahi Derg 2019;25(5):427-432 DOI: 10.5505/tjtes.2018.26050 Submitted: 06.05.2018 Accepted: 05.12.2018 Online: 09.08.2019

Copyright 2019 Turkish Association of Trauma and Emergency Surgery 
a decrease in bacterial contamination and inflammation. ${ }^{[3]} \mathrm{A}$ previous study evaluated the potential effects of several antibiotics used intra-abdominally, and it was reported that the degree of adhesiveness was lower in the antibiotic-treated groups than in the saline-treated control group. ${ }^{[4]}$ However, to our knowledge, to date, there has been no comparison made of the dosages and durations of antibiotics, which remained under-researched.

The present study aimed to investigate the effects on the formation of adhesions and cytokine levels of ertapenem lavage administered at different doses and durations in an experimental abdominal sepsis model.

\section{MATERIALS AND METHODS}

The present study was conducted with the approval of Dokuz Eylül University Animal Experiment Ethics Committee (İzmir, Turkey). This study was performed on 28 Wistar strain male rats, each aged six months and weighing 200-250 g. All the rats were housed in standard animal chambers and cages at a room temperature of $20-22^{\circ} \mathrm{C}$ in the Animal Laboratory of Dokuz Eylül University, with a relative humidity of $50-60 \%$ and at 12/12 hours dark/light cycle until the end of the experiment. The rats were fed with standard feed and water (ad libitum). During the experiment, the rats were weighed daily, and the feed per cage and water consumption were monitored.

\section{Surgical Procedure}

The rats were anesthetized using $45 \mathrm{mg} / \mathrm{kg}$ ketamine and 5 $\mathrm{mg} / \mathrm{kg}$ xylazine intraperitoneally. Uncontrolled sepsis was established in rats with a procedure of cecal ligation and puncture. The rats were fasted for 12 hours before the first operation. The anterior abdominal wall was cleaned with $10 \%$ povidone-iodine and shaved. With a $3 \mathrm{~cm}$ incision to the abdominal wall, the abdominal cavity was opened under sterile conditions. The cecum was identified and dissected without any damage to the vascularization. The cecum was then ligated with $4 / 0$ silk suture from the proximal of the ileocecal valve. The cecum was punctured twice with 22 gauge needles in the antimesenteric (avascular) region. After completion of these procedures, the anterior abdominal wall was sutured with $3 / 0$ silk suture. All rats underwent fluid replacement with subcutaneous administration of $5 \mathrm{ml}$ sodium chloride, and postoperative analgesia of $5 \mathrm{mg} / \mathrm{kg}$ xylose was administered subcutaneously.

The rats were randomly separated into four groups one day after the surgical procedure. The first group was accepted as the sham group. Abdominal lavage of $2 \mathrm{ml}$ saline was administered to group 2 as the saline group. A single dose of ertapenem ( $15 \mathrm{mg} / \mathrm{kg}$, Invanz, MSD, Turkey) was administered intraperitoneally to group 3 and the same dosage of ertapenem ( $15 \mathrm{mg} / \mathrm{kg}$, Invanz, MSD, Turkey) was administered intraperitoneally once daily for seven days to group 4 .
All rats were reopened under anesthesia seven days after the first operation, and the abdomens were reopened and examined.

\section{Evaluation Methods}

I) Ascites evaluation: The quantity of ascites in all groups was determined and measured in cc. Bacterial culture analysis was performed from the ascites collected from the rats before each application and at the end of the experiment. Specimens taken for aerobic culture were incubated at $35^{\circ}-$ $37^{\circ} \mathrm{C}$ for $24-48$ hours, on a medium of $5 \%$ sheep blood agar, chocolate agar, and eosin methylene blue (EMB) agar. Samples taken for anaerobic culture were cultivated in 5\% sheep blood agar added to chocolate agar, EMB agar, kanamycin and vancomycin and incubated in a GasPak jar at $35^{\circ}-37^{\circ} \mathrm{C}$ for 48-72 hours.

2) Adhesion scoring: After seven days, the rats were sacrificed with high-dose ether. The abdomens were opened, and the terminal ileum and cecum walls were excised along with the adhesions on their surfaces. Adhesion scoring was applied to the materials examined according to the Bothin et al. method $^{[5]}$ (Table I). Each adhesion was scored with I point, and the total score was obtained. The ascites accumulated within the abdomen was then collected.

Table I. Adhesion scoring

\begin{tabular}{|c|c|}
\hline Scoring & Description \\
\hline 0 & No adhesion \\
\hline+1 & $\begin{array}{l}\text { One adhesion band from the omentum to the target } \\
\text { organ }\end{array}$ \\
\hline+1 & $\begin{array}{l}\text { One adhesion band from the omentum to the } \\
\text { abdominal scar }\end{array}$ \\
\hline+1 & $\begin{array}{l}\text { One adhesion band from the omentum to another } \\
\text { place }\end{array}$ \\
\hline+1 & $\begin{array}{l}\text { One adhesion band from adnexa/epididymis to the } \\
\text { target organ }\end{array}$ \\
\hline+1 & $\begin{array}{l}\text { One adhesion band from adnexa/epididymis to the } \\
\text { abdominal scar }\end{array}$ \\
\hline+1 & $\begin{array}{l}\text { One adhesion band from adnexa/epididymis to } \\
\text { another place }\end{array}$ \\
\hline+1 & $\begin{array}{l}\text { Any other adhesion band except for those described } \\
\text { above }\end{array}$ \\
\hline+1 & Adhesion of the target organ to the abdominal wall \\
\hline+1 & Adhesion of the target organ to the abdominal scar \\
\hline+1 & Adhesion of the target organ to the intestine \\
\hline+1 & Adhesion of the target organ to the liver and spleen \\
\hline+1 & Adhesion to any organ \\
\hline
\end{tabular}

*The target organ was the cecum. 
3) Histopathological evaluation: The tissues were fixed in formol, then, embedded in paraffin blocks after the followup period. Sections 4-5 micrometers in thickness were cut and routine hematoxylin eosin and tricorn staining was applied. Evaluation of the extent of inflammatory cell infiltration (early neutrophil, late plasma, and monocytic cell), maturation of granulation tissue, collagen deposition, fibrosis, re-epithelization and neovascularization of the sections was made under a light microscope by a pathologist. The Abramov histological scoring system was used for the evaluation. ${ }^{[6]}$ Each parameter was evaluated independently. The Abramov system scoring is shown in Table 2.

5) Biochemical and molecular evaluation: Blood samples were taken from the vena cava at the end of the experiment. The serum was separated from the samples and stored at $-80^{\circ} \mathrm{C}$. TNF-alpha molecule was studied using enzyme-linked immunosorbent assay (ELISA). Rat ELISA kits (Biosource International Inc. Camarillo, CA) were used.

6) Statistical analysis: Data analyses were performed using SPSS 22.0 (IBM Corporation, Armonk, New York, USA) software. Conformity of the data to normal distribution was evaluated using the Shapiro-Wilk test. The Kruskal-Wallis $\mathrm{H}$

Table 2. Histological scoring system

$\begin{array}{ll}\text { Amount of granulation } & \text { 0) Absent } \\ \text { tissue, collagen deposit } & \text { I) Low } \\ \text { 2) Medium } & \text { 3) High } \\ \text { Re-epithelization } & \text { 0) Absent } \\ \text { I) Partial } & \text { 2) Completed, but immature and } \\ \text { Neak } & \text { 3) Completed, mature } \\ \text { 0) Absent } \\ \text { I) Presence of I-5 veins in the } \\ \text { large and enlargement area (LEA) } \\ \text { 2) Presence of 6-10 veins in the LEA } \\ \text { 3) Presence of more than I0 veins } \\ \text { in the LEA } \\ \text { 0) Fibroblast absent } \\ \text { Inflammatory cell count } \\ \text { I) Minimal fibroblast } \\ \text { 2) Moderate fibroblast } \\ \text { 3) Heavy fibroblast } \\ \text { I) Neutrophil between 0-25, } \\ \text { 2) Neutrophil between 26-50, }>5 \text { I neutrophil, macrophage }\end{array}$

test was used together with Monte Carlo simulation results in the comparison of independent groups with respect to variables, while the Miller (1966) test was used for the Post Hoc analyses. Spearman's rho test was used to examine the correlations of variables with each other. The data were analyzed at a $95 \%$ confidence level and a value of $p<0.05$ was accepted as statistically significant.

\section{Exclusion Criteria}

1) Rats that lost $20 \%$ of body weight would be sacrificed by high dose ether and excluded from the experiment.

2) In the case of any rat which died before the completion of the experiment, the adhesion scoring would be applied.

\section{RESULTS}

No rat died or lost more than $20 \%$ of its body weight during the experiment.

The adhesion scores of the groups were determined as median 2.5 (range: I-3) in group I, I I.4 (range: 6-15) in group 2, 4.67 (range: 1-6) in group 3, and 2.5 (range: 1-3) in group 4. The adhesion scores of the groups are shown in Figure 1. At the end of the antibiotic treatment, the decrease in the adhesion score was statistically significant $(p<0.00 \mathrm{I})$.

The numbers of micro-organisms and colonies isolated according to the culture results of ascites from the rats are shown in Table 3. The decrease in the number of colonies following antibiotic administration was not found to be statistically significant $(p=0.109)$ (Table 4$)$. All the isolated microorganisms were identified as sensitive to ertapenem.

The histological scores of the groups are shown in Table 5. The relationships between the antibiotic treatment and collagen deposit, neovascularization, fibrosis, and inflammatory cell accumulation were statistically significant in all groups ( $p<0.05$ for all). There was no significant difference between the adhesion and histological scores when group 3 and group 4 were compared with each other $(p>0.05)$.

When all the groups were evaluated, the TNF- $\alpha$ values were determined to be highest in group 2 and lowest in group I.

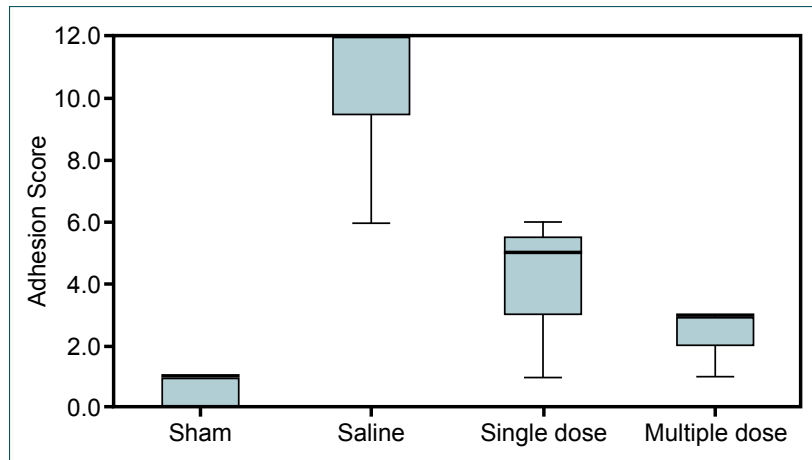

Figure 1. The adhesion score distribution of the groups. 
Table 3. Distribution of breeding micro-organisms

\begin{tabular}{llcl}
\hline Groups & Isolated micro-organism & Number of colonies & Number of rats with reproduction \\
\hline Group 1 & No Reproduction & - & - \\
Group 2 & Coagulase negative staphylococci & $10^{2}$ & 1 \\
& $\alpha$-hemolytic streptococcus & $10^{3}$ & 1 \\
& Haemophilusparainfluenzae & $10^{3} / 10^{4}$ & 2 \\
& Enterococcus spp. & $10^{3}$ & 1 \\
& Corynebacterium spp. & $10^{4}$ & 1 \\
Group 3 & Escherichia coli & $10^{3}$ & 1 \\
& $\alpha$-hemolytic streptococcus & $10^{1}$ & 1 \\
& Enterococcus spp. & $10^{1 / 10^{3}}$ & 2 \\
Group 4 & Escherichia coli & $10^{1}$ & 1 \\
& Haemophilusparainfluenzae & $10^{4}$ & 1 \\
\hline
\end{tabular}

Table 4. Comparison of colony numbers between groups

\begin{tabular}{lc}
\hline Group & Number of colonies \\
\cline { 2 - 2 } & Median (min-max) \\
\hline Group I $(n=7)$ & $0(0-0)$ \\
Group $2(n=7)$ & $100(105-0)$ \\
Group $3(n=7)$ & $2,857.1(103-0)$ \\
Group $4(n=7)$ & $1,428.6(104-0)$ \\
Total $(n=28)$ & $31.8(105-0)$ \\
P-value & 0.109 \\
\hline
\end{tabular}

The TNF- $\alpha$ levels of the groups are shown in Figure 2. The findings showed that there was a significant correlation between the TNF- $\alpha$ values and the adhesion score $(p<0.05)$.

\section{DISCUSSION}

Adhesions occur as a result of the contact of two damaged peritoneum surfaces. Following a peritoneal injury, the balance between coagulation and the fibrinolytic system is disrupted in favor of coagulation. As a result, fibrin deposits form a matrix for the growth of fibrinocollagenous tissue. Thus, fibroblasts are stored in the extracellular matrix. If the matrix metalloproteinase proenzymes (MMP) break the extracellular matrix, this results in normal healing. If MMP is inhibited by tissue inhibitors, peritoneal adhesions occur. ${ }^{[7]}$ Plasminogen-activator inhibitor (PAI) has been detected at high levels in peritoneal tissue and fluid during intra-abdominal infections, thereby inhibiting fibrinolysis. ${ }^{[8]}$ Inflammatory exudate accumulating in bacte-

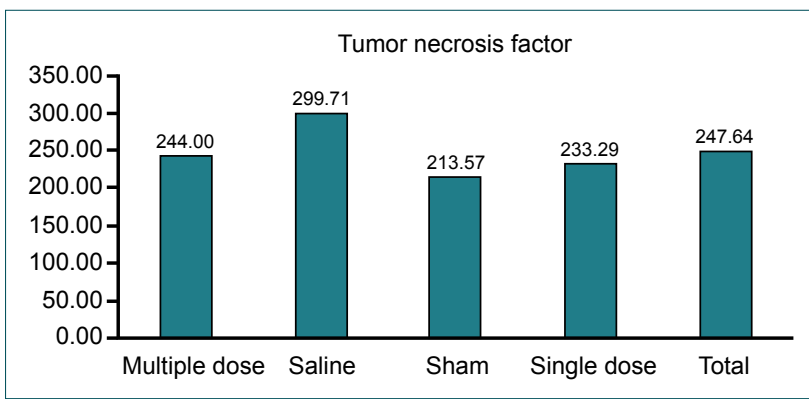

Figure 2. TNF- $\alpha$ values of the groups.

Table 5. Comparison of the histopathological scores between the groups

\begin{tabular}{|c|c|c|c|c|}
\hline \multirow[t]{2}{*}{ Group } & \multirow{2}{*}{$\frac{\text { Collagen deposit }}{\text { Median (min-max) }}$} & \multirow{2}{*}{$\frac{\text { Neovascularization }}{\text { Median (min-max) }}$} & \multirow{2}{*}{$\frac{\text { Fibrosis }}{\text { Median (min-max) }}$} & \multirow{2}{*}{$\frac{\text { Inflammatory cell accumulation }}{\text { Median (min-max) }}$} \\
\hline & & & & \\
\hline Group I (n=7) & $1.00(1-1)$ & $1.29(2-1)$ & $1.00(1-1)$ & $1.29(2-1)$ \\
\hline Group $2(n=7)$ & $1.86(2-1)$ & $2.43(3-2)$ & $2.00(3-1)$ & $2.57(3-2)$ \\
\hline Group $3(n=7)$ & $1.57(2-1)$ & $2.43(3-2)$ & $1.43(2-1)$ & $2.7 I(3-2)$ \\
\hline Group $4(n=7)$ & I.7I (2-I) & $2.29(3-2)$ & I.7I (2-I) & $2.14(3-2)$ \\
\hline Total $(n=28)$ & $1.54(2-1)$ & $2.13(3-1)$ & $1.52(3-1)$ & $2.22(3-1)$ \\
\hline$P$-value & 0.010 & 0.001 & 0.005 & $<0.001$ \\
\hline
\end{tabular}


rial peritoneal injury gives rise to fibrin deposits and adhesions. [9] In addition, fibroblasts invading the infection site contribute to the formation of collagen deposits and fibrous adhesions. ${ }^{[10]}$

Adhesion is the first step in colonization and is an important virulence factor. Antibiotics exhibit anti-adhesive effects by inhibiting the expression of adhesions on the bacterial cell surface or by causing modifications in protein expression in bacteria. As a result, antibiotics prevent micro-organisms from binding to the cell surface. ${ }^{[1]}$ Ertapenem is a carbapenem with a broad spectrum of effects. It has a limited effect against Pseudomonas Aeruginosa and Acinetobacter species, ${ }^{[12]}$ and is therefore not expected to affect the resistance profiles of bacteria such as Pseudomonas spp. and Acinetobacter spp. as other carbapenems do. Ertapenem was preferred in this study because it is thought that future use will be more widespread due to the rational use of antibiotics and increased antibiotic resistance over time. No systemic antibiotic was administered, but the local antibiotic effect was evaluated in this study. The potential side effects of systemic antibiotics are thought to be reduced by the use of local antibiotics.

Peritoneal lavage, although previously attempted in the treatment of intra-abdominal infections and adhesions, does not have precise results. Various studies ${ }^{[4,13,14]}$ have reported the use of saline, antibiotic and fibrinolytic agents given during peritoneal lavage. Today, there is no universally accepted peritoneal lavage method and solution. As a result of giving antibiotics with peritoneal lavage, both positive and negative results have been obtained on adhesions. In the peritonitis model performed by researchers, ${ }^{[15]}$ the findings showed that administration of rifampicin with peritoneal lavage both reduced adhesions and improved survival. Similarly, in another study, ${ }^{[4]}$ researchers applied peritoneal lavage with metronidazole, imipenem, ceftriaxone and cefazolin, and showed that cephalosporins and imipenem decreased adhesions in the septic abdomen. In contrast, some studies ${ }^{[16]}$ determined that peritoneal lavage with cefazolin and tetracyclin increased abdominal adhesions in the thenon-septic abdomen. In another research ${ }^{[17]}$ compared chloramphenicol, clindamycin, piperacillin, tobramycin, ceftriaxone, and imipenem with saline, and reported that more adhesions occurred in the antibiotic groups compared to the saline group. In the present study, a statistically significant reduction was detected in the adhesion score at the end of antibiotic administration $(\mathrm{p}<0.00 \mathrm{I})$. There was also a significant correlation between antibiotic administration and reduction of the histological score (collagen deposit, fibrosis, inflammatory cell accumulation, neovascularization) $(p<0.005)$.

Recent studies ${ }^{[18]}$ showed that enteric bacteria and antigens increased adhesion formation after laparotomy. Epithelial repair and secondary wound healing, such as mesothelial regeneration, were seen to be affected by bacterial contamination. It has been thought that a reduction in bacterial contamination and decreased local and systemic inflammation will result in fewer fibrin deposits and intra-abdominal adhesions. ${ }^{[3]}$ In the present study, there was a high correlation between adhesion score and number of colonies $(r=0.539, p=0.003)$. No statistically significant decrease was found in the number of colonies in any of the antibiotic-treated groups in the current study $(p=0.109)$. These may be attributed to various reasons, such as the late delivery of the acid materials in the laboratory and the inability to produce bacteria due to the difficulty in producing anaerobic bacteria.

Theoretically, agents that inhibit contact between the serosal surfaces for more than three days have the potential to inhibit the formation of adhesions. ${ }^{[19]}$ In this study, a single dose of ertapenem was administered to one group, and multiple doses to the other group in the form of a single dose every day for seven days. As a result, a difference was observed between the two groups (single dose and multiple dose) in terms of the duration of antibiotic treatment and adhesion formation but not in respect of the histopathological evaluation $(p>0.05)$. The findings obtained in this study suggest that in cases of surgically-treated peritonitis, irrigation with ertapenem may reduce the formation of adhesions.

TNF- $\alpha$ is an important mediator that has a role in early inflammation and also involved in the formation of adhesions by being released from the mesothelial cells. In a previous rat model experiment, a high level of TNF- $\alpha$ was detected in the peritoneal fluid and serum, correlated with the severity of adhesions. ${ }^{[20]}$ In the present study, a significant correlation was also found between TNF- $\alpha$ level and the adhesion score.

For the findings of the current study to come into clinical use, some modifications need to be made in practice. No intravenous antibiotics were administered during this study, and only local antibiotics were used. Intraperitoneal antibiotherapy alone has been shown to inhibit the entire peritoneal bacterial reproduction, and although the effect was brief, it has been seen to continue if repeated at frequent intervals. [21] Another study showed that administration of antibiotic peritoneal lavage concomitantly with systemic antibiotics to patients in generalized peritonitis reduced mortality, morbidity, and length of hospital stay. ${ }^{[22]}$ Therefore, in clinical practice, it can be considered that intraperitoneal antibiotic administration alone may not suffice, and it should be administered together with intravenous antibiotherapy. If the present study comes into clinical use, drainage may be required to perform intraperitoneal lavage. However, drainage may bring about serious complications that may require surgical intervention, such as wound infection, bleeding from the abdominal vessels, and, more rarely, intestinal obstruction and/or incarceration. ${ }^{[23]}$

It is thought that rational antibiotic use and the use of single-dose intraperitoneal ertapenem during the surgical procedure may be beneficial and sufficient to reduce current surgical complications. Since intra-abdominal adhesions may cause chronic abdominal pain, infertility, and ileus at later stages, the current experiment may be considered to contribute to 
the literature. There is a need for further studies and clinical practice on this subject.

\section{Conflict of interest: None declared.}

\section{REFERENCES}

1. Cinel I, Dellinger RP. Advances in pathogenesis and management of sepsis. Curr Opin Infect Dis 2007;20:345-52. [CrossRef]

2. Gogos CA, Drosou E, Bassaris HP, Skoutelis A. Pro- versus anti-inflammatory cytokine profile in patients with severe sepsis: a marker for prog nosis and future therapeutic options. J Infect Dis 2000;181:176-80.

3. Bicalho PR, Mayrink CA, Fernandes F, Alvarenga DG, Nunes TA, Reis FA, et al. Chlorhexidine as a factor that promotes peritoneal adhesions in rats with induced peritonitis. Acta Cir Bras 2013;28:641-5. [CrossRef]

4. Kayaoğlu HA, Ozkan N, Yenidoğan E, Köseoğlu RD. Effect of antibiotic lavage in adhesion prevention in bacterial peritonitis. Ulus Travma Acil Cerrahi Derg 2013;19:189-94. [CrossRef]

5. Bothin C, Okada M, Midtvedt T, Perbeck L. The intestinal flora influences adhesion formation around surgical anastomoses. Br J Surg 2001;88:143-5. [CrossRef]

6. Abramov Y, Golden B, Sullivan M, Botros SM, Miller JJ, Alshahrour A, et al. Histologic characterization of vaginal vs. abdominal surgical wound healing in a rabbit model. Wound Repair Regen 2007;15:80-6. [CrossRef]

7. Arung W, Meurisse M, Detry O. Pathophysiology and prevention of postoperative peritoneal adhesions. World J Gastroenterol 2011;17:4545-53.

8. van Goor H, de Graaf JS, Grond J, Sluiter WJ, van der Meer J, Bom VJ, et al. Fibrinolytic activity in the abdominal cavity of rats with faecal peritonitis. Br J Surg 1994;81:1046-9. [CrossRef]

9. van Goor H, Bom VJ, van der Meer J, Sluiter WJ, Bleichrodt RP. Coagulation and fibrinolytic responses of human peritoneal fluid and plasma to bacterial peritonitis. Br J Surg 1996;83:1133-5. [CrossRef]

10. Thompson JN, Whawell SA. Pathogenesis and prevention of adhesion formation. Br J Surg 1995;82:3-5. [CrossRef]
11. Lorian V, Ernst J. Effects of antibiotics on bacterial structure and their pathogenicity. Pathol Biol (Paris) 1987;35(10 Pt 2):1370-6.

12. Shah PM, Isaacs RD. Ertapenem, the first of a new group of carbapenems. J Antimicrob Chemother 2003;52:538-42. [CrossRef]

13. Kirdak T, Uysal E, Korun N. Assessment of effectiveness of different doses of methylprednisolone on intraabdominal adhesion prevention. [Article in Turkish]. Ulus Travma Acil Cerrahi Derg 2008;14:188-91.

14. Günaydın M, Güvenç D, Yıldız L, Aksoy A, Tander B, Bıçakcı Ü, et al. Comparison of substances used for prevention of intra-abdominal adhesions: an experimental study in rats. Turkiye Klinikleri J Med Sci 2012;32:337-45. [CrossRef]

15. Jallouli M, Hakim A, Znazen A, Sahnoun Z, Kallel H, Zghal K, et al. Rifamycin lavage in the treatment of experimental intra-abdominal infection. J Surg Res 2009;155:191-4. [CrossRef]

16. Rappaport WD, Holcomb M, Valente J, Chvapil M. Antibiotic irrigation and the formation of intraabdominal adhesions. Am J Surg 1989;158:435-7. [CrossRef]

17. Sortini D, Feo CV, Maravegias K, Carcoforo P, Pozza E, Liboni A, et al. Role of peritoneal lavage in adhesion formation and survival rate in rats: an experimental study. J Invest Surg 2006;19:291-7. [CrossRef]

18. Cahill RA, Wang JH, Redmond HP. Enteric bacteria and their antigens may stimulate postoperative peritoneal adhesion formation. Surgery 2007;141:403-10. [CrossRef]

19. Gomel V, Urman B, Gurgan T. Pathophysiology of adhesion formation and strategies for prevention. J Reprod Med 1996;41:35-41.

20. Kaidi AA, Gurchumelidze T, Nazzal M, Figert P, Vanterpool C, Silva Y. Tumor necrosis factor-alpha: a marker for peritoneal adhesion formation. J Surg Res 1995;58:516-8. [CrossRef]

21. Krukowski ZH, Al-Sayer HM, Reid TM, Matheson NA. Effect of topical and systemic antibiotics on bacterial growth kinesis in generalized peritonitis in man. Br J Surg 1987;74:303-6. [CrossRef]

22. Khan BA, Hassan G, Shant MS, Kadri SM, Rather RA. Role of intraperitoneal antibiotic lavage in peritonitis. JK Science 2003;2:67-9.

23. Loh A, Jones PA. Evisceration and other complications of abdominal drains. Postgrad Med J 1991;67:687-8. [CrossRef]

\title{
DENEYSEL ÇALIŞMA - ÖZET
}

\section{Çekal ligasyon ve puncture yöntemi uygulanan sıçanlarda ertapenem etkinliğinin gösterilmesi \\ Dr. Başak Göl Serin, ${ }^{1}$ Dr. Şükran Köse, ${ }^{2}$ Dr. Osman Yılmaz, ${ }^{3}$ Dr. Mehmet Yıldırım, ${ }^{4}$ Dr. İlkay Akbulut, ${ }^{2}$ Dr. Süheyla Serin Senger, ${ }^{2}$ Dr. Gülgün Akkoçlu, ${ }^{3}$ Dr. Gülden Diniz, ${ }^{5}$ Dr. Süha Serin ${ }^{6}$}

\author{
${ }^{1}$ Hopa Devlet Hastanesi, Enfeksiyon Hastalıkları ve Klinik Mikrobiyoloji Kliniği, Artvin \\ ${ }^{2}$ Sağlık Bilimleri Üniversitesi Tepecik Eğitim ve Araştırma Hastanesi, Enfeksiyon Hastalıkları ve Klinik Mikrobiyoloji Kliniği, İzmir \\ ${ }^{3}$ Dokuz Eylül Üniversitesi Tıp Fakültesi, Laboratuvar Hayvanları Bilimi Anabilim Dalı, İzmir \\ ${ }^{4}$ Sağlık Bilimleri Üniversitesi Bozyaka Eğitim ve Araştırma Hastanesi, Genel Cerrahi Kliniği, İzmir \\ ${ }^{5}$ Sağlık Bilimleri Üniversitesi Tepecik Eğitim ve Araştırma Hastanesi, Patoloji Kiliniği, İzmir \\ ${ }^{6}$ Urla Devlet Hastanesi, Acil Tıp Kliniği, İzmir
}

AMAÇ: Karın içi yapışıklıklar halen önemli bir sorundur. Bakteriyel dekontaminasyon sağlanmasıyla karın içi yapışıklıkların azalacağı düşünülmektedir. Geçmişte çeşitli antibiyotikler septik karında adezyon formasyonunun önlenmesi için kullanılmıştır. Bu çalışmanın amacı çekal ligasyon ve puncture yöntemi ile sepsis modeli oluşturulan sıçanlarda ertapenem etkinliğinin gösterilmesidir.

GEREÇ VE YÖNTEM: Çalışmada ağırıkları 200-250 gr arasında değişen, erkek cinsi, 28 adet Wistar cinsi sıçan kullanıldı. Sıçanlar rastgele dört gruba ayrıldı. Tüm gruplarda çekal ligasyon ve puncture yöntemiyle bakteriyel peritonit oluşturuldu. Grup I sham grubu olarak kabul edildi; grup 2'ye serum fizyolojik (SF), grup 3'e ertapenem tek doz, grup 4'e ertapenem her gün günde bir doz intraperitoneal yolla verildi. Cerrahiden yedi gün sonra karın içi yapışıklıklar değerlendirildi, histopatolojik inceleme yapıldı, elde edilen asitesten mikrobiyolojik inceleme yapıldı. Sıçanlardan alınan kan örneklerinden TNF- $\alpha$ bakıldı.

BULGULAR: Ertapenem uygulaması ile adezyon skoru anlamlı derecede azaldı $(\mathrm{p}<0.00 \mathrm{I})$ ve fibrozis skorları anlamlı derecede düşük olarak bulundu $(p=0.005)$. Tüm gruplar arasında, antibiyotik uygulaması ile koloni sayısındaki azalma arasındaki ilişki anlamlı bulunmadı $(p=0.109)$. Tek doz ertapenem verilen grup ile multipl (çok doz) ertapenem verilen grup arasında istatistiksel olarak fark saptanmadı $(p=I)$.

TARTIŞMA: Bu veriler ışı̆̆ında septik karında, ertapenemle peritoneal lavajın adezyonu önlemede etkin olduğu görülmektedir. Tek doz ile çok doz antibiyotik uygulaması sonunda adezyon skorlarında fark saptanmadığından operasyon sonrası tek doz uygulamanın yeterli olabileceği düşünülmektedir. Sonuçların bir klinik çalışmada değerlendirilmesi gerektiği düşünülmektedir.

Anahtar sözcükler: Ertapenem; sepsis; sıçan.

Ulus Travma Acil Cerrahi Derg 2019;25(5):427-432 doi: 10.5505/tjtes.2018.26050 